\title{
SOCIAL SUPPORT NETWORK OF NURSES FOR THE CARE OF THEIR OWN CHILDREN ${ }^{1}$
}

\author{
Bruna Caroline Rodrigues², Verônica de Azevedo Mazza3 , Ieda Harumi Higarashi
}

\footnotetext{
${ }^{1}$ Extracted from the dissertation research - Mother nurse: the process of caring for the children in the contexto $f$ life and work, presentde to the Graduate Program in Nursing, State University of Maringá. Paraná, Brazil, in 2012.

2 M.Sc. in Nursing. R.N. at Unidade de Pronto Atendimento Zona Norte. Paraná, Brazil. E-mail: bruninhaamd@hotmail.com

${ }^{3}$ Ph.D. in Nursing. Adjunct Professor at the Nursing Graduate Program of the Federal University of Paraná. Paraná, Brazil. E-mail: mazzas@ufpr.br

${ }^{4}$ Ph.D. in Education. Associate Professor at the Nursing Department and the Nursing Graduate Program of the State University of Maringá. Paraná, Brazil. E-mail: ieda1618@gmail.com
}

\begin{abstract}
This exploratory descriptive study, using a qualitative approach, aimed to characterize the social support of nurses in the care of their own children. The participants were ten nurses who were mothers, selected through a snowball method. Data collection occurred from November 2011 to January 2012 through semi-structured interviews and construction of families' genograms and ecomaps. Data were analyzed through Bardin content analysis, leading to the establishment of two categories: (1) Returning to work: the importance of family support and (2) The family and their interactive contexts: types of bonds. The social support network of the family is essential to the lives of these women, who need support, assistance and guidance in directing their activities in everyday overload.
\end{abstract} KEYWORDS: Mothers. Nursing. Work. Social support.

\section{REDE SOCIAL DE APOIO DE ENFERMEIRAS-MÃES NO CUIDADO COM OS FILHOS}

RESUMO: Trata-se de um estudo descritivo-exploratório, com abordagem qualitativa, que objetivou caracterizar o suporte social de enfermeiras-mães no processo de cuidar dos filhos. Os sujeitos da pesquisa foram 10 enfermeiras-mães. A seleção das mães se deu pela técnica de bola de neve. A coleta de dados ocorreu no período de novembro de 2011 a janeiro de 2012, por meio de entrevista semiestruturada e construção de genogramas e ecomapas das famílias. Os dados foram analisados conforme técnica de análise de conteúdo de Bardin, que levaram à configuração de duas categorias: (1) O retorno ao trabalho: importância do apoio familiar e (2) A família e seus contextos interativos: tipos de vínculos. A rede de apoio social da família torna-se essencial na vida destas mulheres, que precisam do suporte, auxílio e orientação no encaminhamento de suas atividades neste cotidiano de sobrecarga.

PALAVRAS CHAVE: Mães. Enfermagem. Trabalho. Apoio social.

\section{RED SOCIAL DE APOYO DE LAS MADRES ENFERMERAS EN EL CUIDADO CON LOS HIJOS}

RESUMEN: Se trata de un estudio descriptivo-exploratorio con abordaje cualitativo, cuyo objetivo fue caracterizar el apoyo social de las madres enfermeras en el cuidado de los niños. Los sujetos fueron 10 madres enfermeras. En el proceso de selección de las madres se utilizó la técnica de bola de nieve. Los datos fueron recolectados en el período de noviembre de 2011 hasta enero de 2012, por medio de la realización de entrevistas, utilizando una pauta semiestructurada y la construcción de genogramas y ecomapas de las familias. Los datos fueron analizados a partir del técnica de análisis de contenido de Bardin que llevó a la creación de dos categorías: (1) El volver al trabajo: la importancia del apoyo familiar y (2) La familia y sus contextos interactivos: tipos de enlaces. La red de apoyo social de la familia es esencial para la vida de estas mujeres, que necesitan el apoyo, la asistencia y orientación en la dirección de sus actividades en la sobrecarga diaria.

PALABRAS CLAVE: Madres. Enfermería. Trabajo. Apoyo social. 


\section{INTRODUCTION}

The arrival of a child causes many and varied changes in the lives of the couple and the family, especially when they experience this situation for the first time. In addition to the expectations with regard to the arrival of the baby, feelings of anxiety and fear of the unknown become part of the family routine.

Mothers experience a tangle of mixed feelings around the experience of motherhood; on one hand, they are happy with the birth of their children, and at the same time, they experience fear and anxiety about the unknown. ${ }^{1}$ The extent and impact of this experience for mothers are such that some authors affirm the risks of mental disorders in these women after giving birth due to the often conflicting character of motherhood. ${ }^{2}$

It is, thus, an intense period of change and construction of new concepts and responsibilities in which the formation of a bond with a new being is allied with the knowledge of oneself in the exercise of a new role - that of being a mother - with all other responsibilities that such a condition implies.

In this process, and as time goes by, mothers may experience difficulties in childcare related to breastfeeding, child growth and development, feeding practices and return to work, delegation of care to third parties, and separation of the couple, among others.

To better cope with complex situations involving the care of the baby, the partner's participation becomes essential - as well as that of friends, family and professionals, in order to contribute to settling any problems, in addition to the psychological support that a mother needs to provide her first child on all ranges of care. ${ }^{1}$ In this regard, social support for the family and, particularly, the mother is essential so that the child is cared for in a wholesome and harmonious way.

The importance of identifying social support networks is highlighted by the process of subsidizing better preparation of proposals for professional care and health services that meet the needs of the families in question. ${ }^{3-4}$

Addressing these situations during the early mother-infant relationship is favored by various professionals and, in particular, the nurse, as a member of the healthcare team that works with health promotion, providing guidance and offering the necessary care. ${ }^{5}$ And when this professional becomes a mother herself, facing the challenge of managing the caring process in relation to her own child? To whom must these nurses who are mothers (mother nurses) turn to in times of trouble? From where does this support come?

The nursing profession has taken on a historically "female" identity and is very much linked to the function exercised by women in society. As a profession eminently exercised by women, nursing retains a feminine essence and is directed at providing care and offering affectionate support to others. In this regard, the attitude of Florence Nightingale in caring for the wounded in the Crimean War in 1854 gave birth to a legacy of service to others as well as persistence and compassion in nursing. ${ }^{6}$

Nursing care has a humanistic character, since it does not end with providing care in sickness but seeks to go beyond to providing support for better living conditions and ensuring the common good. ${ }^{7}$ Thus, it is irrecoverably associated with the concept of caring and the qualities directly related to the role of the mother, who cares for, nourishes and educates.

Despite this unequivocal association, caring assumes for the nurse a character of professional work and not a mere extension of her feminine being. Thus, such as it occurs with other working women, there is an overlap of roles and responsibilities in the exercise of these varied spheres of care.

From this perspective, and because of the multiple roles played by women in today's society, this study is justified in seeking to better understand how nurses, as professionals working with care, experience motherhood and caring for their children with an emphasis on the importance of social support networks in this experience. Therefore, this research aims to characterize the social support of mother nurses in the process of caring for their children.

\section{METHODOLOGY}

This is a descriptive, exploratory study with a qualitative approach. The study site was the city of Maringá, located in the northwest of the state of Paraná, with total area of $488 \mathrm{~km}^{2}$ and population of $357,007.8$

Because this was a qualitative study, we chose, for convenience, to use an intentional sample in order to select cases that could express the topic addressed with greater potential to respond to the central question of the study. In this research, the intentional sample was achieved 
through criteria sampling; selected individuals were those most likely to provide information relevant to the subject, according to some predefined criteria, and considered important for the understanding of the matter. ${ }^{9}$

The research participants were ten mother nurses, selected through a snowball technique; ${ }^{10}$ each participant was invited to indicate someone of her professional or social life to join the search. According to this search strategy, the first respondents indicate others who, in turn, appoint others, and so on. Inclusion criteria were: being a nurse, working professionally on the occasion of motherhood, and having an only child up to preschool age. We opted for smaller children so that we could include in the testimonies and maintain the description of their experiences in caring from birth to the moment of the interview.

The primary subject was considered the one who was first contacted and approached regarding interest in participating in the study. This individual was selected from the researcher's circle of interaction and, as previously pointed out, by criteria of convenience. Other contacts were made by phone or in person through indication of the primary subject.

Data collection occurred from November 2011 to January 2012 and was conducted through recorded interviews using a semi-structured script and the construction of the genogram and ecomap. The script consisted of two parts: first, questions of a more objective character for the characterization of the subjects, and second, open questions aimed at the development of the study's central topic (childcare process, organization of return to work, feelings experienced when delegating maternal functions). Genograms and ecomaps serve to "outline the structures and internal and external interactions of the family", ${ }^{11: 84}$ presenting, in a fairly didactic way, the network of relationships established by each household with the community and the reality in which it is inserted.

The genogram provides data on family and relationships, while the ecomap shows the relationships of the family with other people or institutions beyond the immediate family. ${ }^{11}$ The use of these instruments "enables quick viewing of family relationships, as well as a more complete understanding of the interaction between members and society". 12:69

The study data were collected without pre-determining the number of participating subjects, because the number of individuals was determined by data saturation and to the extent of achievement of the study objectives. We took into account that the number of subjects is in its potential to empirically determine the object in all its magnitudes, since, in the qualitative search, the researcher should worry less about generalization and more about depth, breadth and diversity in the understanding process of the group to be investigated. ${ }^{13}$

Data pertinent to the central theme of the study, the social support network of mother nurses, were analyzed descriptively. We proceeded to the exhaustive reading of the transcribed interviews to identify meaningful units of speech through Bardin's technique of content analysis in the thematic category mode. ${ }^{14}$ Allied to this process, and for didactic organization of pertinent information, we proceeded to elaborate genograms and ecomaps for each participating family. This process was performed manually in a space reserved in the instrument of data collection, the end of the semi-structured script. At this time, the respondents were informed about the purpose of using these tools and about the meaning of each symbol used (Figure 1).

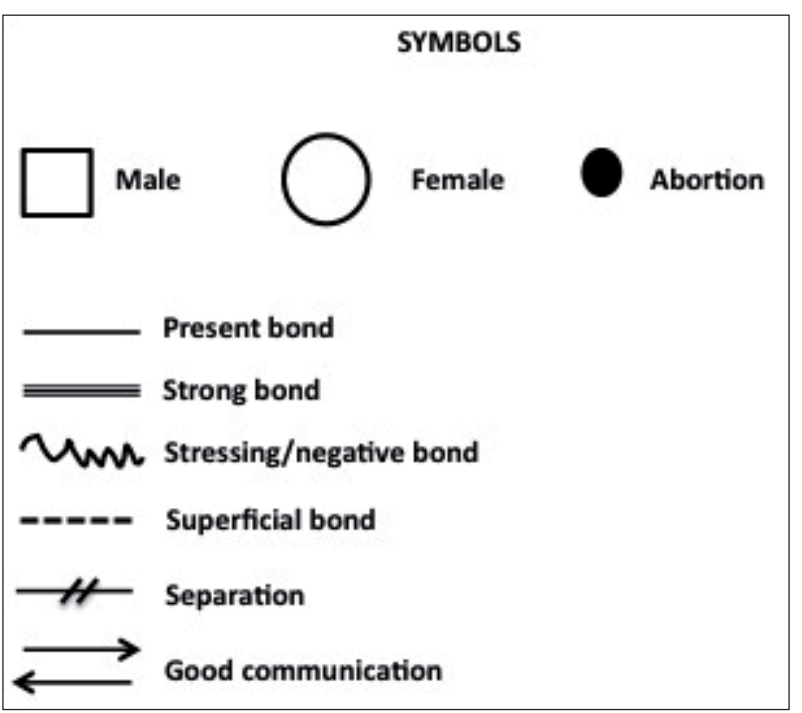

Figure 1 - Symbols used in the construction of the genogram and ecomap of the families

Knowing the family structure; its composition, functions, and roles; and how members are organized and interact with each other and with the environment is vital for the researcher to better understand the relationship among its members. The genogram and ecomap allow the researcher to determine the family concept, generated between the subjects of the ongoing research, and to observe 
how the different roles are played together and in the community. ${ }^{15}$

To produce the genograms, it was decided to build relationship lines from the family generation of the index subject with regard to all the subjects of the previous generation who had many children, keeping the objective outlined in the study in focus.

The analysis occurred simultaneously with data collection, facilitating the assessment of results. The use of the genogram and ecomap has the advantage of being an objective indicator, disclosing interactions that are not identified within the analysis of the testimonies by means of verbal languge. ${ }^{15}$ Each interview was coded by the letter " $\mathrm{e}$ " followed by Arabic numerals, as per their sequence of performance, to maintain the anonymity of the interviewees.

The study was valued and approved by the Standing Committee on Ethics in Research Involving Human Subjects of the State University of Maringá (under Opinion No. 263/2011).

\section{RESULTS AND DISCUSSION}

Ten nurses participated in the study, with ages ranging from 29 to 46 years old (average of 33 years old), and eight were concentrated in the range of 28 to 35 years old. Mothers' age at birth of the child ranged from 25 to 39 years old (average of 30 years old and mode of 25 years old). Most participants were married, two had a stable union, and two were divorced.

With respect to educational level, four nurses had only one latu senso specialization, and three had two postgraduate degrees at the same level. Apart from having a latu senso specialization, three nurses had stricto senso post-graduate education at the master's level.

Monthly family income ranged from $\mathrm{R} \$ 1,800.00$ to $\mathrm{R} \$ 15,000.00$ (average of $\mathrm{R} \$ 8,260.00$ ); five families had a monthly income of less than $\mathrm{R} \$ 5,000.00$, and four had higher monthly income above $\mathrm{R} \$ 10,000.00$. In most of the families, there were two individuals contributing to the income; in three families, only one person was responsible for the family income, and only one family had four income contributors.

Children's age ranged from eight months to six years old (average of three years old and mode of two years old). Regarding gender, half of the sample consisted of girls and half of boys. The age of the parents varied between 29 and 46 years old (average of 37 years old and mode of 35 years old).

Only three couples had not planned the pregnancy. The most cited reason for mothers justifying the choice of pregnancy at that particular point in their lives was financial and professional stability.

The interpretation of the data to approach the central theme of the study allowed the researcher to depict the outline of the mother nurses' social networks in the process of caring for and educating the children. Here, two thematic categories were established: 1) Return to work: importance of family support and 2) The family and their interactive contexts: types of bonds.

\section{Return to work: importance of family support}

This category deals with the organization of the return to work by the mother nurse from the perspective of the follow-up in baby care. The term "mother nurses" is justified by a chronological issue, as this woman was already a nurse (a professional with care as her work object) before experiencing motherhood and being faced with the challenge of caring for her own child.

The subjects reported support received from a family member as the main contributor in this transition of care process; in some families, the child remained part of the day under the care of a babysitter or in daycare. The remaining respondents reported making use of daycare, babysitters, or both, such as their child's caregivers during their working hours.

My mother went to my house at 6 in the morning, crossed the entire city and stayed with [daughter] at home until about 9:30/10:00, then left the [daughter] at day-care [...] (e1).

At first, I would leave my child at daycare, but my mother-in-law said: 'no, he's too young, you can leave him with me and I'll take care of him'. I was sort of embarrassed to leave him with her, because she had not taken care of babies in a long time; one never knows [...] he ended up staying right there with her (e2).

My sister is a physiotherapist, and we had already decided that when I got pregnant, she would be with my child part time, so I would pay her and another girl to help [...] she's his godmother, so she is also a mother, so to speak (e8).

The grandmother herself decided to stop working. So I gave her some financial help, so that my mother could stop working and dedicate herself to my [daughter] (e9). 
These testimonies showed that the option to take over care came, in most cases, from the actual family member, usually the grandmother, mobilized by affection and concern regarding the care of their grandchildren. In this sense, mothers reported feeling much safer and at peace by leaving their children with someone from their family rather than delegating such a function to nannies or institutions. This observation was made from the following statements:

[...] you trust more because it is someone from your family; it is not someone you hired to take care [...] (e2).

[...] if it were just the babysitter, I do not know how it would have been, no. But because my sister was close by, I felt more at peace, because I know my sister would never let someone mistreat [...] (e8).

[...] what helped was the fact that my mother was living here, so my daughter does not have to be with strangers. I have a little more peace of mind at work, because I know she is well cared for. So this gives me greater comfort to exercise my function here (e9).

[...] I did not want to put her in daycare [...] I was very relieved because she was staying with my mother and I know she would be well cared for (e10).

The feelings of peacefulness and security in relation to the care of children positively influence the lives of these families, reflected mainly in the nurses' working lives. The realization of maternal activities by other people present in the family network of care options allows mothers to feel that these activities are being carried out by people worthy of their trust. ${ }^{16}$ Accordingly, such trust induces an accuracy of the mother's professional functions, allowing the woman to better exercise her roles. ${ }^{16}$

The mothers in this study reported participation and full support of partners with regard to training and education of children, with the exception of two mothers who were separated. In a study performed within nursing faculty, the lack of support in the lives of these professionals, together with the multiple activities developed by them, led to stress, fatigue and anxiety. ${ }^{16}$ Even working outside the home, and despite counting on a social support network, the monitoring of the trajectory of their offspring and the feeling of responsibility to care for the family remains incorporated into a woman's character. ${ }^{17-18}$

Although the responsibility of caring for the child is socially rooted to the mother, the partner plays a fundamental role in relation to family support, which is capable of generating self-confidence in the couple, contributing to settling problems both in professional life and in their day-to-day lives. ${ }^{19}$ Due support by other family members increases the mother's feeling of wellbeing, security and accomplishment, contributing to success in breastfeeding and promoting the construction of more solid bonds between mother and child.

From this perspective, regarding the breastfeeding process of the child, interviewees reported the positive influence of the nanny and husband in exclusive breastfeeding, allowing the extension of this practice until the baby was six months old.

[...] at breastfeeding times, for example, my husband left his work and picked up my son. He and the nanny took him over to my job so that I could breastfeed him and, at night, also [...]. The interval was 15/20 minutes; if I were to drive home and drive back to work, there would not be enough time [...]. He would leave school earlier to go and pick him up.... (e7)

The partner and family group may have a direct influence on the practice of breastfeeding, both positively and negatively, depending on the pre-natal guidance received. ${ }^{20}$ The proper provision of guidance, support and encouragement for breastfeeding is required by all women and their families, even in the case of health professionals who have knowledge acquired in college, because the moment of pregnancy, especially of the first child, translates into a huge set of emotions and insecurities.

In this sense, the authors affirm that women need social, professional and family support during pregnancy and childbirth, especially in relation to successful breastfeeding - considered an essential practice - with the paternal influence playing a prominent role in this process. ${ }^{21}$

\section{The family and their interactive contexts: types of bonds.}

Through the construction of genograms and ecomaps, it was found that the families studied had varied structure and dynamics. Many were of the nuclear type (consisting of a union between adults and a child), others were single parents (composed of only the mother nurse and a child), and one was of the extensive type (consisting of ascendants, parents and a child).

Figure 2 presents the family relationships from the perspective of family informants E1, E4 and E7. These ecomaps were selected because 
they illustrate different family configurations, representing nuclear, single parent and extensive family structures, respectively, inserted into their corresponding social support networks.

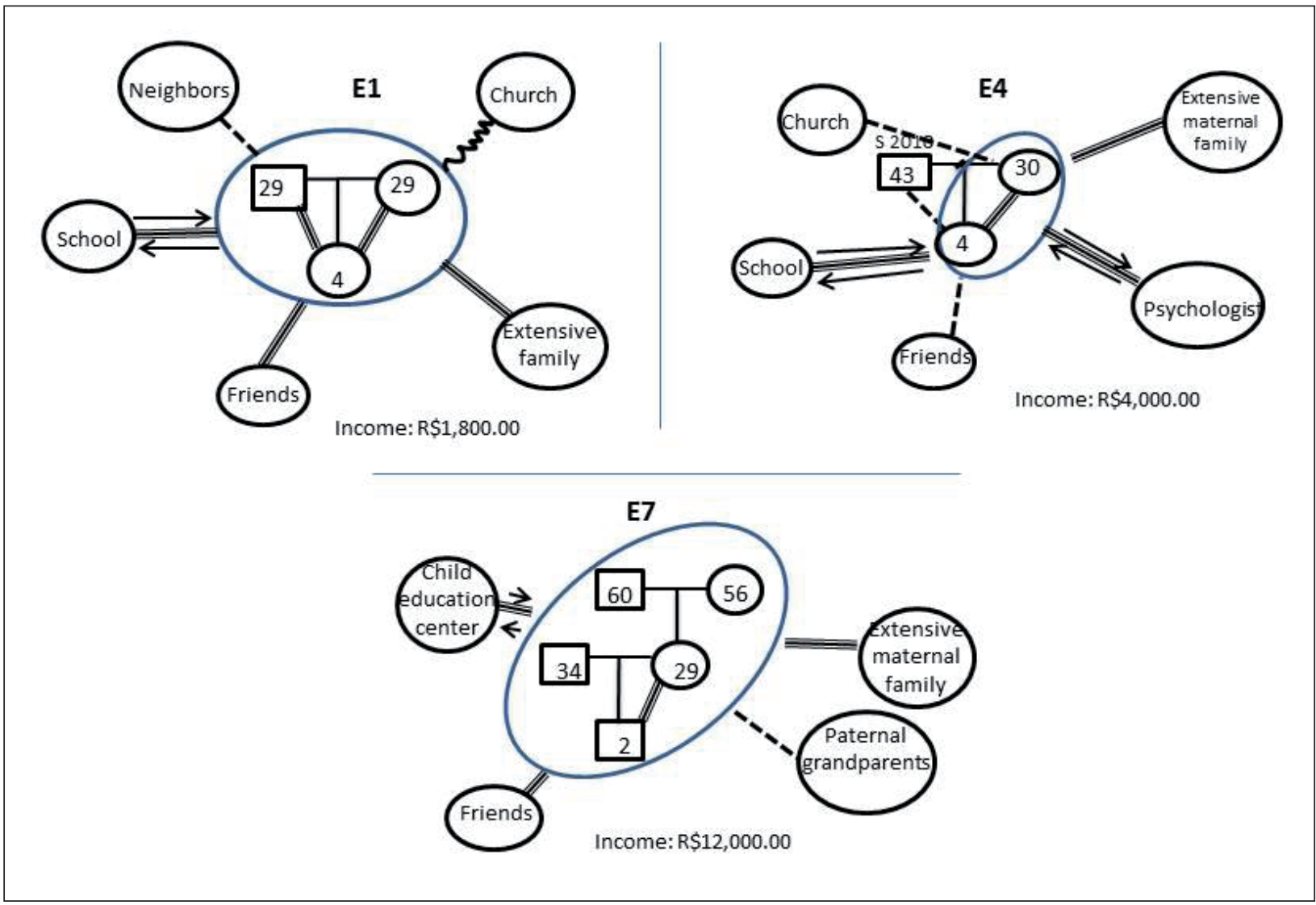

Figure 2 - Genograms and ecomaps of informants' families E1, E4, and E7

The construction of family genograms and ecomaps has revealed links and more consistent relationships of households with extended family, represented mainly by their maternal grandparents. This important social support strengthens the maternal role in the process of caring for and educating children, given that the family and emotional ties of the mother are determinants for consolidating support outside the parental level.

Regarding paternal grandparents, some mothers reported strong relationships; others qualified the relationships as superficial; another mentioned a lack of relationship (separate couple); and one reported a shallow and stressful relationship. Some mothers attributed the fragility of this relationship and the difficulty in establishing a bond to the geographical distance. The literature confirms the importance of partner and grandparent participation, assisting women in overcoming life's difficulties, mitigating negative experiences, and enabling more peacefulness for mom and baby, as the mom feels supported and sheltered in dealing with problems. ${ }^{1,4}$

On being asked about family members other than maternal and paternal grandparents, uncles and aunts presented a significant participation in the support network, justified by the affinity and/or geographic proximity of residence. Most mothers also reported the existence of strong ties with friends. Study indicates that, despite geographically close relatives representing the main source of support, the presence of friends proves indispensable in the social support network of families, especially in times of difficulty. ${ }^{22}$

With regard to neighbors, many mothers reported superficial relationships, giving reasons related to the recent change and distinct daily routine. Only one interviewee mentioned having a strong relationship with the neighborhood, while other mothers reported having no type of relationship with this population. The fragility found in this study of the relationships between families and their neighbors may be explained by 
the lack of time present in postmodern society. For our participants, this fact may result from the numerous functions performed by these women, which make it impossible for them to establish bonds even with people who share the same geographic area.

One aspect of the study findings that drew attention was the presence of strong relationships and constant dialogue with the school or Child Education Center, corroborating a study held in a city of the metropolitan region of Curitiba in which families also referred to a very close relationship with these institutions. ${ }^{4}$ This fact was attributed to interviewees' positive evaluation regarding the school structure, daily contact and affinity between school institution and family. It is worth emphasizing the importance of this finding, because, in addition to teaching, the school serves as a support for the individual in training and her family. Establishing linkages between them can help overcome anxieties, doubts and difficulties, which, together, are received and processed so that this experience results in maturity. ${ }^{23}$

With respect to the criteria used by the family in choosing the educational institution for the sheltering and care of a child, aspects such as physical facilities and general infrastructure of the school were mentioned, such as election criteria. Mothers also indicated that the type of floor, the cleaning of bathrooms, and food preparation were contributing factors at the time of making the decision. Recommendation by other people was the second most cited criterion, and the smallest amount of children per room or at school, the teaching method adopted, financial order issues, and geographic proximity were also set as important factors in the selection of the school.

Of the mothers who delegated childcare to nannies, interviewees reported that feelings of love, affection, honesty and prior knowledge of the person were the criteria used to choose these professionals.

In terms of religion, the majority reported superficial links with the church, some reported maintaining a strong relationship with their church and religion, others reported not having any type of relationship, and one mother reported the existence of a stressful relationship since she and her husband were from different religions, thus generating conflicts between the couple. This aspect differed from the findings of other studies on the subject that pointed to religion and the church as very strong elements in families' social support networks. ${ }^{4,22,24}$ It should be noted, however, that the studies in question dealt with serious health conditions - that is, situations of hardship and suffering. In such cases, it is common for people to seek spirituality as a source of support.

In addition to these traditional institutions in the social network context, mothers also cited the participation of professionals such as psychologists and teachers in the support and guidance of care:

[...] there are some things [about which] I have some doubt, that I do not know how far I must go, with discipline, with strictness, and the psychologist gives me some basis [...] she gives me opinion, sees things that maybe the mother does not see, helps me work these difficulties that I have with my daughter and that my daughter also has with me, she helps in this exchange. (e4)

Informant $\mathrm{e} 4$ is part of a single-parent family composed of mother and daughter. The psychologist appears in this context to be a source of support and dialogue, providing guidance for decision-making in daily family life and child's education.

\section{FINAL CONSIDERATIONS}

The many roles assumed by women, such as being a mother, a wife and a professional, generate an overlap of functions in addition to physical and mental fatigue, because even after the inclusion of women in the labor market, they remain as the primary caregivers for children and the house. Although some men contribute to household chores and childcare, such participation does not reach the level given by the woman in this context.

Not infrequently, this multifaceted woman finds herself overwhelmed by the myriad of commitments and responsibilities that she started to assume without setting aside the culturally assigned roles of the female protagonist.

In this study, it was observed that the greatest source of social support for these women, nurses and mothers is constituted by the very extension of their families, such as grandparents, uncles, aunts, nieces and nephews. It was noted that there are strong links between nuclear families and their extensions, motivated by interest in helping and feelings of affection among all.

This research shows the lack of relationship between families and neighbors and the church. These two elements of the traditional social support network of families appear to have fragile, 
nonexistent, or even stressing connections. This fact can be attributed to the lack of time that marks the current society, hindering a more effective interaction with the social network - in this case, religious institutions - as well as moments of conviviality with the community and neighborhood. In the specific case of mother nurses, concomitant employment relationships can become an aggravating factor in the time constraint for such activities of social coexistence.

The social support network of the family, therefore, becomes essential to the life of these women, who need support, assistance and guidance in directing their activities in everyday overload. The family interactions with the people around them, as well as with the various segments of society, facilitate decision-making, assist in overcoming problems, and contribute to a better quality of life for the working woman and her family.

The limitations of this study can be attributed to its qualitative character and the small number of subjects, which do not allow generalization of findings to the entire population of women, mothers and nurses. It is hoped, however, that this study can serve as a space for reflection by other professionals and researchers in the field of nursing in order to stimulate new studies that seek to understand our way of being and professional doing in their correlations with the personal and social being.

\section{REFERENCES}

1. Rapoport A, Piccinini CA. Maternidade e situações estressantes no primeiro ano de vida do bebê. PsicoUSF. 2011 Maio-Ago; 16(2):215-25.

2. Rowan C, Bick D, Bastos MH. Postnatal debriefing interventions to prevent maternal mental health problems after birth: exploring the gap between the evidence and UK policy and practice. Worldviews Evid Based Nurs. 2007 Jun; 4(2):97-105.

3. Brusamarello T, Guimarães AN, Labronici LM, Mazza VA, Maftum MA. Redes sociais de apoio de pessoas com transtornos mentais e familiares. Texto Contexto Enferm. 2011 Jan-Mar; 20(1):33-40.

4. Alexandre AMC, Labronici LM, Maftum MA, Mazza VA. Mapa da rede social de apoio às famílias para a promoção do desenvolvimento infantil. Rev Esc Enferm USP. 2012 Abr; 46(2):272-79.

5. Souza MHN, Gomes TNC, Paz EPA, Trindade CS, Veras RCC. Estratégia acolhimento mãe-bebê: aspectos relacionados à clientela atendida em uma unidade básica de saúde do município do Rio de Janeiro. Esc Anna Nery. 2011 Out-Dez; 15(4):671-77.
6. Souza ML, Sartor VVB, Padilha MICS, Prado ML. O cuidado em enfermagem - uma aproximação teórica. Texto Contexto Enferm. 2005 Abr-Jun; 14(2):266-70.

7. Cunha RR, Pereira LS, Gonçalves ASR, Santos EKA, Radünz V, Heidemann ITSB. Promoção da saúde no contexto paroara: possibilidade de cuidado de enfermagem. Texto Contexto Enferm. 2009 Jan-Mar; 18(1):170-6.

8. Ministério do Planejamento, Orçamento e Gestão. IBGE - Instituto Brasileiro de Geografia e Estatísticas - Cidades - Sistema de Informações - Maringá - PR. [página da internet]. Brasília (DF): MS; 2011 [acesso em: 2011 Out 05]. Disponível em: http:/ / www.ibge. gov.br/cidadesat/topwindow.htm?1

9. Taylor SJ, Bogdan R. Introduction to qualitative research methods. Nova York (EUA): John Wiley \& Sons; 1998.

10. Biernacki P, Waldorf D. Snowball samplingproblems and techniques of chain referral sampling. Sociol Methods Res. 1981 Nov; 10:141-43.

11. Wright LM, Leahey M. Enfermeiras e famílias: um guia para avaliação e intervenção na família. $4^{\text {a }}$ ed. São Paulo (SP): Roca; 2008.

12. Sassá AH. Assistência domiciliar de enfermagem ao bebê nascido com muito baixo peso e sua família [dissertação]. Maringá (PR): Universidade Estadual de Maringá. Programa de Pós-Graduação em Enfermagem; 2011.

13. Caldeira DA, Gonçalves E. Avaliação de impacto da implantação da Iniciativa a Hospital Amigo da Criança. Arch Pediatr Urug. 2009 Jun; 80(2):144-49.

14. Bardin, L. Análise de conteúdo. Lisboa (PT): Edições 70; 2011.

15. Nascimento LC, Rocha SMM, Hayes VE. Contribuições do genograma e do ecomapa para o estudo de famílias em enfermagem pediátrica. Texto Contexto Enferm. 2005 Abr-Jun; 14(2):280-6.

16. Merighi MAB, Jesus MCP, Domingos SRF, Oliveira DM, Baptista PCP. Ser docente de enfermagem, mulher e mãe: desvelando a vivência sob a luz da fenomenologia social. Rev Latino-Am Enferm [online]. 2011 Jan-Fev [acesso 2012 Jun 02]; 19(1):8telas. Disponível em: http://www.redalyc. org/articulo.oa?id=281421953022

17. Spíndola T. Mulher, mãe...e trabalhadora de enfermagem. Rev Esc Enferm USP. 2000 Dez; 34(4):354-61.

18. Almeida LS. Mãe, cuidadora e trabalhadora: as múltiplas identidades de mães que trabalham. Rev Depart Psicol UFF. 2007 Jul-Dez; 19(2):411-22.

19. Rocha LP, Almeida MCV, Silva MRS, Cezar-Vaz MR. Influência recíproca entre atividade profissional e vida familiar: percepção de pais/mães. Acta Paul Enferm. 2011 Mai-Jun; 24(3):373-80.

20. Takemoto AY, Santos AL, Okubo P, Bercini LO, Marcon SS. Preparo e apoio à mãe adolescente para 
a amamentação. Cienc Cuid Saude. 2011 Jul-Set; 10(3):444-51.

21. Silva BT, Santiago LB, Lamonier JA. Apoio paterno ao aleitamento materno: uma revisão integrativa. Rev Paul Pediatr. 2012 Jan-Mar; 30(1):122-30.

22. Di Primio AO, Schwartz E, Bielemann VLM, Burille A, Zillmer JGV, Feijó AM. Rede social e vínculos apoiadores das famílias de crianças com câncer.
Texto Contexto Enferm. 2010 Abr-Jun; 19(2):334-42.

23. Svartman B. Transubjetividade - sociedade atual: a importância das redes de apoio. Rev SPAGESP. 2003 Dez; 4(4):29-36.

24. Dias J, Nascimento LC, Mendes IJM, Rocha SMM. Promoção de saúde das famílias de docentes de enfermagem: apoio, rede social e papéis na família. Texto Contexto Enferm. 2007 Out-Dez; 16(4):688-95. 